Nationalities Papers

\title{
The Journal of Nationalism and Ethnicity
}

ASSOCIATION FOR THE STUDY OF NATIONALITIES 


\title{
Nationalities Papers
}

\author{
EDITOR-IN-CHIEF \\ Peter Rutland \\ Wesleyan University, USA
}

BOOK REVIEW EDITOR

Roland Spickermann, University of Texas of the Permian Basin

ASSOCIATE EDITORS

Şener Aktürk, Koç University, Turkey

Monika Baar, University of Groningen, The Netherlands

Stephen Deets, Babson College, USA

V.P. ("Chip") Gagnon, Ithaca College, USA

Marlene Laruelle, George Washington University, USA

David Marples, University of Alberta, Canada

Harris Mylonas, George Washington University, USA

Srdja Pavlovic, University of Alberta, Canada

Aviel Roshwald, Georgetown University, USA

Peter Vermeersch, University of Leuven, Belgium

ASSISTANT EDITOR

Lydia Tomkiw, Columbia University, USA

EDITORIAL BOARD

Dominique Arel, University of Ottawa, Canada; Stefano Bianchini, University of Bologna, Italy;

Florian Bieber, Karl-Franzens-Universität Graz, Austria; Fotini Christia, MIT, USA; Karl Cordell, University of Plymouth, UK, David Crowe, Elon University, USA; Ineta Dabašinskienè, Vytautas Magnus University, Lithuania; Dejan Djokic, Goldsmiths. University of London, UK; Alexandra Goujon, University of Dijon, France; John Hall, McGill University, Canada; Jeremy King, Mount Hollyoke College, USA; Andrew Ludanyi, Ohio Northern University, USA; Aleksandra Milicevic, University of North Florida, USA; Brendan O'Leary, University of Pennsylvania, USA; Margaret Paxson, Kennan Institute, USA; Sébastien Peyrouse, George Washington University, USA; Michael Rywkin, City College, USA; Gwendolyn Sasse, University of Oxford, UK; Edward Schatz, University of Toronto, Canada; Alfred C. Stepan, Columbia University, USA; Gearóid Ó Tuathail, Virginia Tech, USA; Timothy Waters, Indiana University, USA; Theodore R. Weeks, Southern Illinois University, USA; Stefan Wolff, University of Birmingham, UK; Susan Woodward, The Graduate Center, City University of New York, USA; Demet Yalçın Mousseau, Koç University, Turkey

Abstracting and indexing services

Nationalities Papers is currently noted in Geographical Abstracts: Human Geography, Geobase, Historical Abstracts, International Bibliography of the Social Sciences (IBSS), International Political Science Abstracts, Sociological Abstracts, Zeller Verlag (IBZ/IBR) and America: History and Life.

ISSN 0090-5992

(C) 2015 Association for the Study of Nationalities

PAST EDITORS

Stephen Horak, Eastern Illinois University, USA (1972-1984)

Orest Subtelny, York University, Canada (1985-1986)

Henry Huttenbach, The City College of the City University of New York, USA (1987-1998)

Nancy Wingfield, Northern Illinois University, USA (1999-2002)

Steve Sabol, University of North Carolina, USA (2002-2009)

Florian Bieber, Karl-Franzens-Universität Graz, Austria 


\section{NATIONALITIES PAPERS \\ The Journal of Nationalism and Ethnicity \\ Volume 43 Number 5 September 2015}

\section{CONTENTS}

Special Section: War, violence, and the military during late socialism and transition Guest Editor: Jan Claas Behrends

War, violence, and the military during late socialism and transition.

Five case studies on the USSR, Russia, and Yugoslavia

Jan Claas Behrends

Dedovshchina on trial. Some evidence concerning the last Soviet generation of "sons" and "grandfathers"

Alena Maklak

Between "ethnocide" and "genocide": violence and Otherness in the coverage of the Afghanistan and Chechnya wars

Philipp Casula

"Some call us heroes, others call us killers." Experiencing violent spaces: Soviet soldiers in the Afghan War

Jan Claas Behrends

Dead heroes and living deserters: the Yugoslav People's Army and the public of Valjevo, Serbia, on the verge of war 1991

Robert Lučić

Chechen women in war and exile: changing gender roles in the context of violence

Alice Szczepanikova

\section{Articles}

Positing "not-yet-nationalism": limits to the impact of nationalism theory on Kurdish historiography

Alexander Maxwell and Tim Smith

The October 1905 pogroms and the Russian authorities

Victoria Khiterer

\section{Book Reviews}

Steven A. Barnes, Death and redemption: the Gulag and the shaping of

Soviet society

Wilson T. Bell

Michael Gorham, After newspeak: language culture and politics in Russia from Gorbachev to Putin

Aziz Burkhanov

Alan Patten, Equal recognition: the moral foundations of minority rights 
Joanne McEvoy, Power-sharing executives. Governing in Bosnia, Macedonia, and Northern Ireland

Adis Merdzanovic

Ioana Bunescu, Roma in Europe: The politics of collective identity formation Aidan McGarry

Lawrence Markowitz, State erosion: unlootable resources and unruly elites in Central Asia

Alexey V. Malashenko 


\title{
Nationalities Papers
}

\author{
Subscription Information: \\ Annual Subscription, Volume 43, 2015 \\ Inst. Print and online: $£ 880 / € 1,167 / \$ 1,458$ \\ Inst. Online only: $\quad £ 770 / € 1,021 / \$ 1,276$ \\ Personal: $\quad £ 204 / € 270 / \$ 335$ \\ (Plus tax where applicable)
}

Nationalities Papers is a peer-reviewed journal, published on behalf of the Association for the Study of Nationalities by Routledge Journals, an imprint of Taylor \& Francis, an Informa business, 4 Park Square, Milton Park, Abingdon, Oxfordshire OX14 4RN, UK.

Taylor \& Francis has a flexible approach to subscriptions, enabling us to match individual libraries' requirements. This journal is available via a traditional institutional subscription (either print with online access, or online only at a discount) or as part of a Subject or Collection Library. For more information on our sales packages please visit http://www.tandfonline.com/page/librarians.

All current institutional subscriptions include online access for any number of concurrent users across a local area network to the currently available backfile and articles posted online ahead of publication.

Subscriptions purchased at the personal rate are strictly for personal, non-commercial use only. The reselling of personal subscriptions is prohibited. Personal subscriptions must be purchased with a personal cheque or credit card. Proof of personal status may be requested.

Back issues: Taylor \& Francis retains a three year back issue stock of journals. Older volumes are held by our official stockists to whom all orders and enquiries should be addressed: Periodicals Service Company, 351 Fairview Ave., Suite 300, Hudson, New York, 12534, USA. Tel: + 1518537 4700; fax: + 1518537 5899; email: psc@ periodicals.com.

Ordering information: Please contact your local Customer Service Department to take out a subscription to the Journal: USA, Canada: Taylor \& Francis, Inc., 325 Chestnut Street, 8th Floor, Philadelphia, PA 19106, USA. Tel: + 1800354 1420; Fax: + 1215625 2940. UK/Europe/Rest of World: T\&F Customer Services, Informa UK Ltd, Sheepen Place, Colchester, Essex, CO3 3LP, United Kingdom. Tel: + 44 (0) 207017 5544; Fax: + 44 (0) 207017 5198; Email: subscriptions@tandf.co.uk.

Dollar rates apply to all subscribers outside Europe. Euro rates apply to all subscribers in Europe, except the UK and the Republic of Ireland where the pound sterling rate applies. If you are unsure which rate applies to you please contact Customer Services in the UK. All subscriptions are payable in advance and all rates include postage. Journals are sent by air to the USA, Canada, Mexico, India, Japan and Australasia. Subscriptions are entered on an annual basis, i.e. January to December. Payment may be made by sterling cheque, dollar cheque, euro cheque, international money order, National Giro or credit cards (Amex, Visa and Mastercard).

Copyright $(C 2015$ Association for the Study of Nationalities. All rights reserved. No part of this publication may be reproduced, stored, transmitted, or disseminated, in any form, or by any means, without prior written permission from Taylor \& Francis, to whom all requests to reproduce copyright material should be directed, in writing.

Disclaimer:

The Association for the Study of Nationalities and our publisher Taylor \& Francis make every effort to ensure the accuracy of all the information (the "Content") contained in our publications. However, The Association for the Study of Nationalities and our publisher Taylor \& Francis, our agents, and our licensors make no representations or warranties whatsoever as to the accuracy, completeness, or suitability for any purpose of the Content. Any opinions and views expressed in this publication are the opinions and views of the authors, and are not the views of or endorsed by the Association for the Study of Nationalities and our publisher Taylor \& Francis. The accuracy of the Content should not be relied upon and should be independently verified with primary sources of information. The Association for the Study of Nationalities and our publisher Taylor \& Francis shall not be liable for any losses, actions, claims, proceedings, demands, costs, expenses, damages, and other liabilities whatsoever or howsoever caused arising directly or indirectly in connection with, in relation to or arising out of the use of the Content. Terms \& Conditions of access and use can be found at http://www.tandfonline.com/page/terms-and-conditions

Taylor \& Francis grants authorization for individuals to photocopy material for private research use, on the sole basis that requests for such use are referred directly to the requestor's local Reproduction Rights Organization (RRO). The copyright fee is $£ 25.00 / € 30.00 /$ $\$ 40.00$ exclusive of any charge or fee levied. In order to contact your local RRO, please contact International Federation of Reproduction Rights Organizations (IFRRO), rue du Prince Royal, 87, B-1050 Brussels, Belgium; e-mail: IFRRO@skynet.be; Copyright Clearance Center Inc., 222 Rosewood Drive, Danvers MA 01923, USA; e-mail: info@copyright.com; Copyright Licensing Agency, 90 Tottenham Court Road, London W1P 0LP, UK; e-mail: cla@cla.co.uk. This authorization does not extend to any other kind of copying, by any means, in any form, and for any purpose other than private research use.

Nationalities Papers, ISSN 0090-5992, is published six times a year by Taylor \& Francis Group, 4 Park Square, Milton Park, Abingdon, OX14 4RN, United Kingdom. The US annual subscription price is $\$ 1,458$. Airfreight and mailing in the USA by agent named Worldnet Shipping Inc., 156-15, 146th Avenue, 2nd Floor, Jamaica, NY 11434, USA. Periodicals postage paid at Jamaica NY 11431.

US Postmaster: Send address changes to Nationalities Papers, Worldnet Shipping Inc., 156-15, 146th Avenue, 2nd Floor, Jamaica, NY 11434, USA.

Subscription records are maintained at Taylor \& Francis Group, 4 Park Square, Milton Park, Abingdon, OX14 4RN, United Kingdom.

Air Business Ltd is acting as our mailing agent.

For more information on Taylor \& Francis' journal publishing program, please visit our website: www.tandfonline.com. 